\title{
The Production of Gold Wire in Antiquity
}

\section{HAND-MAKING METHODS BEFORE THE INTRODUCTION OF THE DRAW-PLATE}

\section{Andrew Oddy}

Researeh Laboratory, The British Museum, London

Many centuries before the invention of wire-drawing the early Greeks and Romans were making beautiful articles of jewellery from gold wire. After an account of the history of wire production, the hand-making methods that were available in antiquity are revietved and the successful simulation of their techniques is described.

Wire is something which we very much take for granted in the twentieth century. It is essential for modern life in all aspects of electrical and mechanical engineering and hundreds of thousands of miles are manufactured each year in a wide range of metals and alloys. The technique of manufacture involves the gradual reduction of the thickness of a metal rod

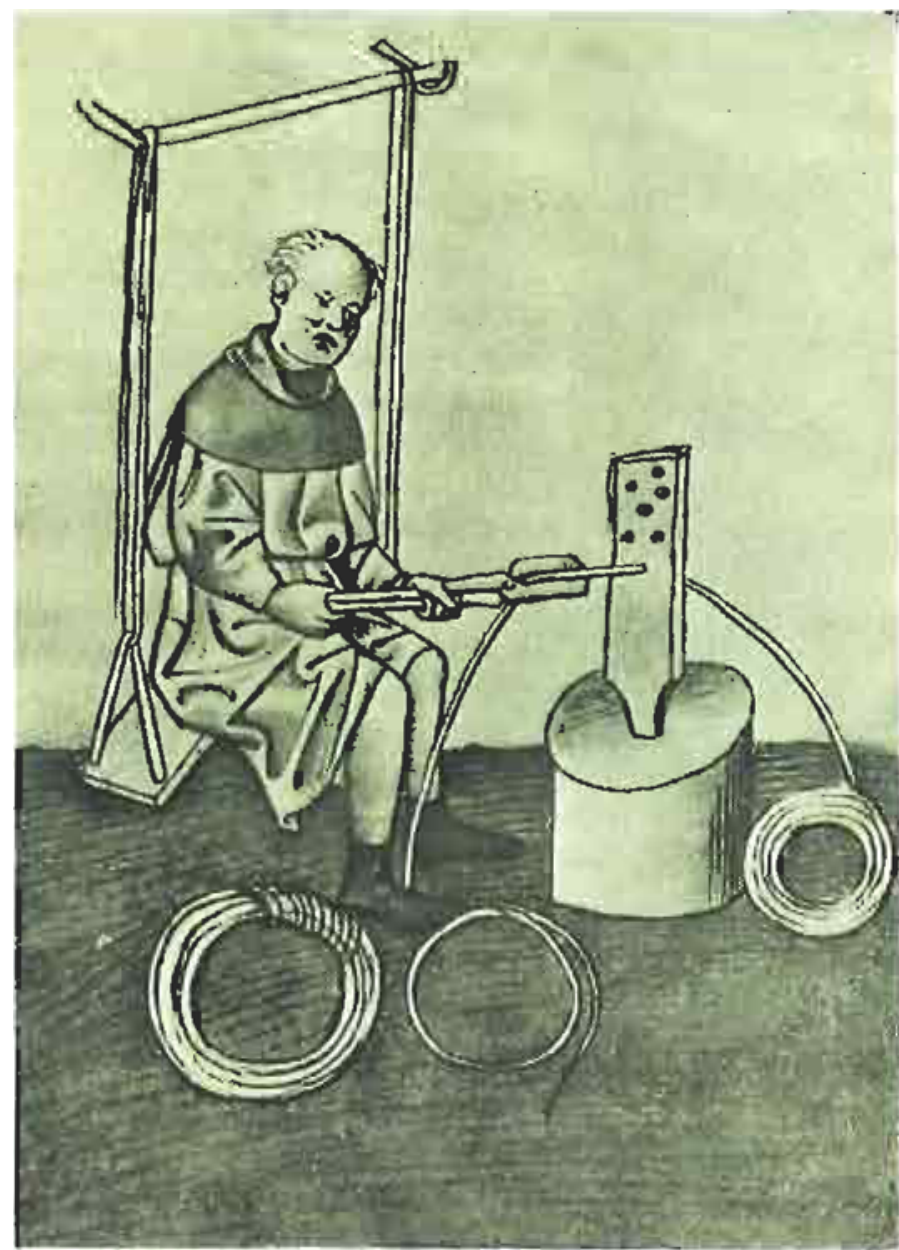

by drawing it through a series of holes of steadily decreasing diameter, so that the resulting wire increases in length with each pass. In modern mechanised practice the wire is essentially infinite in length, but before the introduction of machinery wire was produced by hand, the essential tools being a firmly clamped "draw-plate", containing the series of tapering holes, and a very strong pair of pliers with which to grip the wire and pull it through the next smallest hole. A steady pull is essential, and in the most primitive technique the artisan gripped the end of the wire projecting through the die and then either walked steadily backwards across the workshop or sat on a swing with his feet on the anvil on which was clamped the draw-plate, so that he could move backwards and forewards by straightening or bending his legs. This process is illustrated in Figure I from a late fourteenth century manuscript, known as the Mendel Brothers Hausbuch, in the Municipal Library in Nüremberg (1).

The earliest historical reference to the draw-plate is by Theophilus (2) in his early twelfth ccntury A.D. treatise on workshop practice, where he also describes several

Fig. I Probnbly the Grst illusiration of wire drawing through a draw-plate, this picture from a manuscript of A.D. 1389 the IIausbuch compiled in Germany by the Mlendel Brothera, slows a monk sitting on a swinging seat ao that he ean push backwardy with his legs agningt the anvil loolding the draw plate, the tongs holdisg the wire being fastented to his belt 


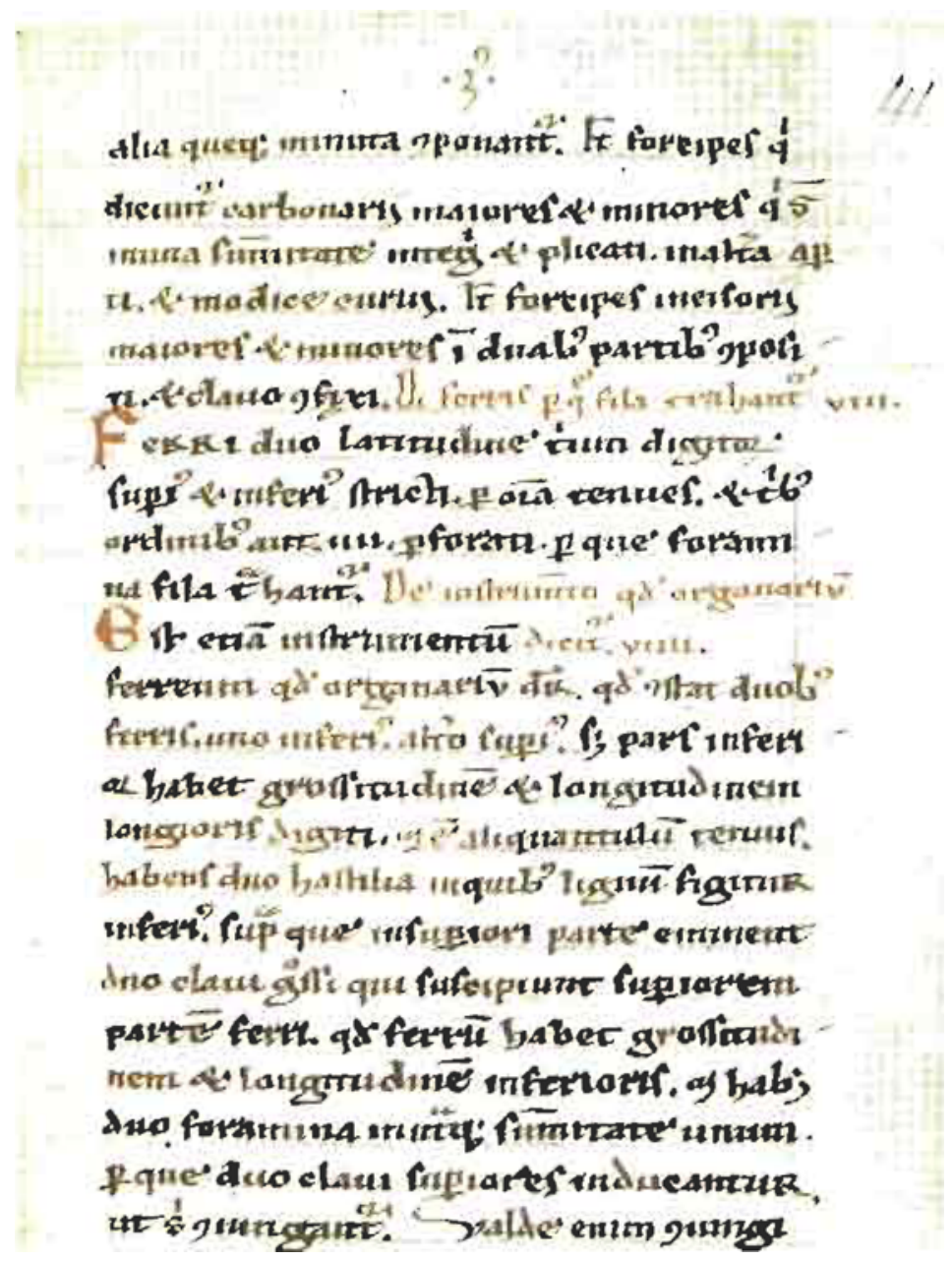

lig. 2 The enrliont lilersary ruference to the draw-plate accurs in the De Divertis Artibus of the Gorman monk Theophilua, written in the eurly part of the iwelfth century. The aljort paswage from his Book III, Ciapter VIII, De Furris per Quae Fila Trahmutur, can be secn beginming six lines down this page (with the heading in red) from a thirleesth century munumeript copy in the Britinh Mugeum.

In Iranalation tho paragge rendm: Iron through which Wires nre Drawn There are two iror implouncuts, three fingers wide, narrok' at the top and lootlom, llin throughont and with three or four rows of boles tlyrongh which wiret mny be linwn different types of pincers, though he does not specify which was used for wire-drawing. Figure 2 illustrates the relevant section from a thirteenth century manuscript in the British Museum.

Hornmel has described the use of these two basic tools as they were still in use in China until recently (3), and he and Wulf (4) and Necdham (5) all illustrate versions of the first machines developed for wire-drawing in which a windlass is used to draw the wirc, which is then taken up on a drum, allowing much longer continuous lengths to be produced than are possible entirely by hand.

The actual date and place of the invention of the draw-place are unknown, but wire was certainly made by hand for many centuries before this, and so we cannot simply equate the appearance of wire with the invention of the draw-plate. Aitchison (6) claims that the Persians knew how to draw wire by the sixth or fifth centurics B.c., but gives no authority for this statement, though Singer et al (7) suggest that gold wire used in filigree on a Persian rhyton of this period must have been drawn because the wire is so even, and Sucherland makes a similar claim for an Egyptian diadem of around 1800 B.c. (8). However this is no proof, as hand-made gold wire can be extremely even in diameter, and the main visual evidence for drawn wire is the presence of multitudes of paralicl striations on the surface, although these are not mentioned. Needham (5), quoting Fremont (9), states that wire drawing has been known since Hellenistic times (third to second centuries B.C.). However these statements are also not supported by a close examination of relevant antiquitics (10) though Anastasiadis claims to have scientific evidence for wire-drawing by the Grecks (11). He has made a metallurgical section of a copper wire and interpreted the observed elongation of the grains as evidence for wire-drawing, but this type of distortion of the crystals could also be the result of making wirc by hand from an ingot by hammering, and in the absence of the characteristic paraliel striations on the surface (see below), the use of the draw-plate cannot be said to be proved.

A date at the other extreme, of the middle of the 
fourtenth century (possibly in Nüremberg), is suggested by Beckmann (12) on the grounds that there is a change in name of the people who make wire at this period from "wire-smith" 10 "wiredrawer", but in the light of more recent discoveries of hand draw-plates dating from the Viking period $(13,14)$ and the cven earlice Merovingian period $(13,15)$, this change of title is more probably to be associated with the mechanisation of the process and, in particular, with the introduction of water power to turn the drum on which the wire was wound (16).

\section{Medieval Records}

Onc potential source of information about the practice of wire-drawing in medieval times lies in the records of the guilds which controlled the craft, and these can be supplemented by a study of town records in which artisans are mentioned. Thompson (16) and Lewis (17) have drawn attention to the thirteenth century A.D. rules which governed the operation of a guild in Paris for the making of gold and silver wire which were collected and published by Etienne Boileau in 1837 (18), but unfortunately the data given all concerns the management of the workshop and working conditions for the employees rather than any details of the technology of the processes which were used. In Coventry, England, the craft of wiredrawing was reorganised in $A, D$. I435 as a result of a certain amount of overlapping of techniques beiween different craftsmen and of complaints about the quality of the wire being produced. To avoid further confusion the Mayor reorganised the craft into separate units and defined the operations which each type of craftsman was to carry out (19).

Iig. 3 An engraving blhowing the drawfug of gold ant silver wire at line end of the seventeently century, from the Abbildwng der gemern miistichen Ifanpstänete by Chrisloph Weigel, published in Regenspurg in 1698
There is little doubt that further searching among the medieval records of centres which were famous for wire-drawing in later centuries would add considcrably to our knowledge of the organisation and technology of the craft at the crucial period when it was developing from a simple hand or bench-top process into a minor mechanised industry. The development of the technology was, no doubt, stimulated by increasing demands for the products and, as far as iron wire is concerned, the demand for mail armour on the one hand and for wire carding brushes in the wool industry on the other must have been major factors. There is little doubt that any improvement in the methods of drawing iron wire would be reflected in the workshops producing wire in the softer and more precious metals, though data on these workshops are scanty, no doubt because the demands for gold and silver wire were not great and could be satisfied by the output from small workshops until relatively recently.

With the invention of printing, illustrations of such workshops, initially as woodcuts but later as copper or steel engravings, become more common, and the most famous printed illustrations of machinery for drawing wire are in the De La Pirotechnia of Vannoccio Biringuccio (20). Another workshop scene of a wire-drawer was cut by Jost Amman (21) and is illustrated by Lewis (17), and among those

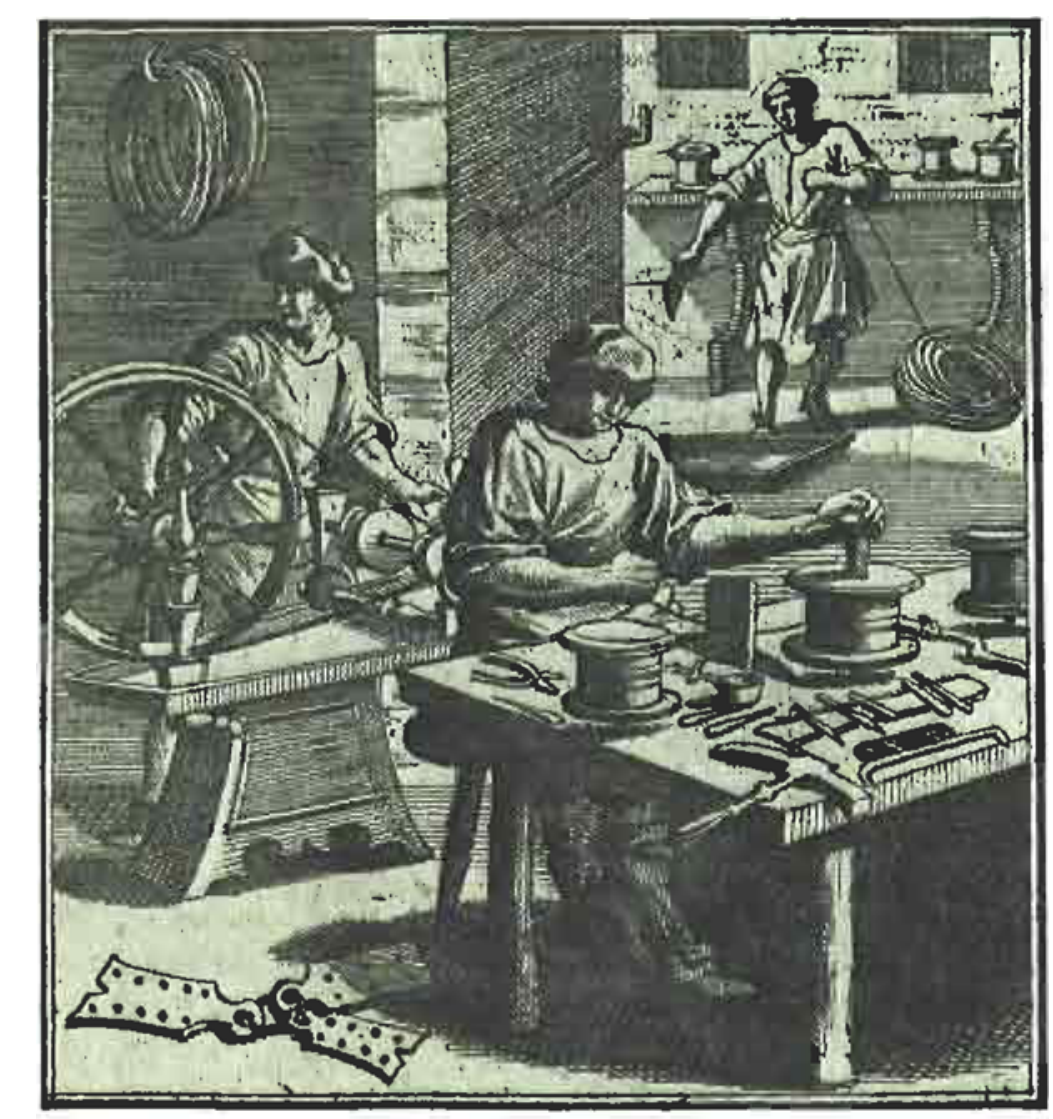


from the following century are three illustrations published by Christoph Weigel in 1698 (22), one of which, showing work in gold and silver, is reproduced in Figure 3.

Several discussions of the making of wire in Britain in the post-medieval period are available (23 and references thercin), but they are mostly concerned with the jron wire industry.

In an attempt to discover the origin of the wiredrawing plate, the carliest historical reference remains the Treatise of Theophilus, though Singer et al say that iron wire was made by forging until the tenth century when the draw-plate was invented (24). This statement contrasts with another later in their book in which they accept wire-drawing in early Persia (7).

\section{Archaeological Sources}

If historical sources can take wire-drawing back only to the twelfth century, archaeology can go further as draw-plates are well known from Viking contexts; Petersen lists nineteen possible draw-plates from Norway, the carliest being attributed to the Merovingian period (13). Vierck knows of a late sixth century A.D. draw-plate (15), but one of the problems about the use of archaeological finds is in their interpretation, as a very similar tool to a wire-drawing die was used for forming the heads on nails. Thomsen and Thomsen (25) have recently discussed this problem, and Oldeberg, in his comprehensive treatise on metalworking technique in the early medieval period, illustrates dies but cautiously describes them as tools for making either wire or nails (26). This uncertainty about the original use of a die complicates the interpretation of archacological discoveries in the absence of either associated wire or of some other technological feature of the die itself, but Ohlhaver has suggested that iron plates pierced with a scrics of tapering holes which are connected on the wider side by a groove must be wire-drawing dies and that the groove is a means of supplying lubricant (27). Dr. Birgit Arrhenius has recently published a wiredrawing dic of the Viking period from Birka in Sweden (14) (Figure 4) which is of particular interest because the conical holes in the iron plate are fitted with replaccable inserts. However metallurgical examination has shown that these inserts are made of softer iron than the rest of the plate and Arrhenius interprets this as evidence that the tool was used for drawing wire in the precious metals, rather than in iron, and this fits in with other jewellery-making activity which was current at Birka. More recently Thomsen and Thomsen have discussed the question of when the draw-plate was invented, and they have shown both theoretically and practically that wire can be drawn through dies made of the same metal as the wire (28). They use this as evidence to support

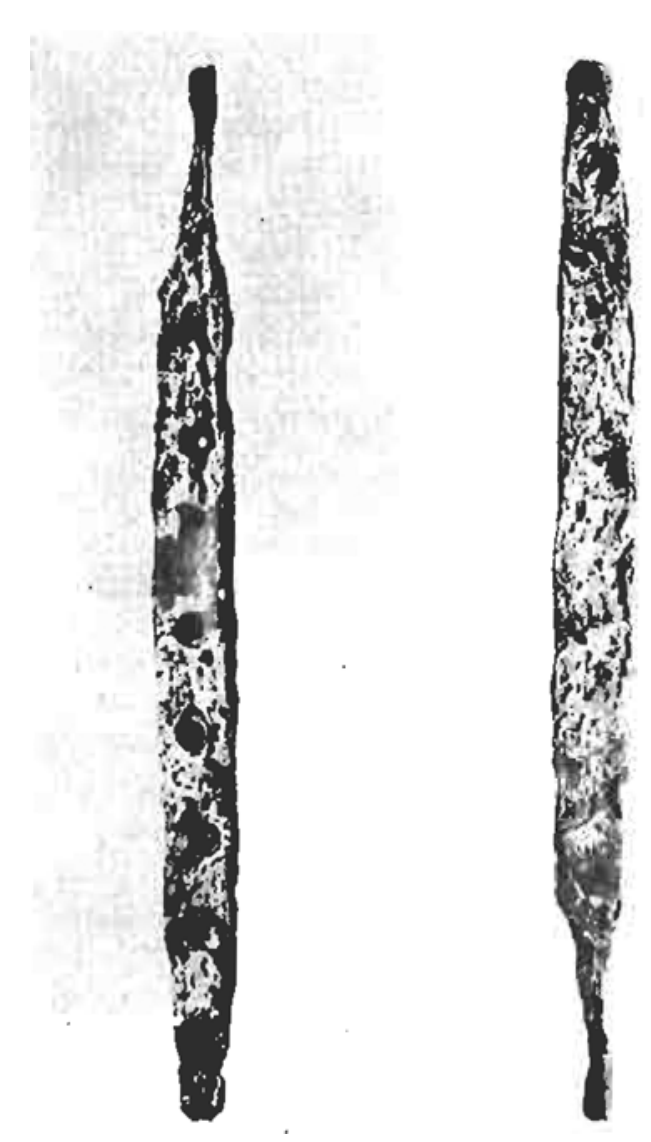

Fig. 1 A wire-drawing die from the Viking period (ninılı or terilh century A,D.) recently found in Sweden. This has scven comical holes with soft irou inaerts to facilitale the drawing of gold and silver wire

Photegraph by courtexy or Dr. Birgit Arrhenius

those authors who think that wire was drawn in antiquity and that one of the reasons that drawplates have not survived is that they were made of "materials considered too scarce or too precious to be left behind as appurtenarces of the goldsmiths' workshops and may have gone into the crucibles for melting and reuse".

In the long run this type of argument is self-defeating as it can never be proved and, in the absence of draw-plates and historical sources, the only way to solve the problem of the introduction of the drawplate is to study surviving wires in the light of a series of observed criteria which will distinguish between wire which was drawn or which was hand made.

One of the carliest investigators to make critical observations on the wirc components of antiquities was Caroline Ransome Williams in her catalogue of Egyptian jewellery belonging to the New York Historical Society (29), though her observations and 
deductions have seldom bcen used by those studying ancient technology until Diane Lee Carroll incorporated them into her discussions of wirc-drawing in antiquity $(30,31)$. The controversy about the date of the introduction of wire-drawing has raged for almost a century, with Schliemann stating that the gold wire found in a treasure dating from the third millennium B.c. at Troy was drawn but Flinders Petrie being equally adamant that all the ancient wires he had seen showed evidence of hammering.

Diane Lee Carroll had discussed this problem more fully, and also the contemporary aspect of it in which the presence or absence of drawn wirc has becn used by several authors as a critcrion for the authenticity of disputed "antiquities". What, however, is lacking is an objective discussion of the possible ways of making wire by hand with a list of the criteria which can be used to distinguish one from another. The matter is complicated by the fact that although there are four distinct ways of making wire by hand, it is possible to merge one into another to some extent to produce various hybrid variations.

\section{Reproduction of \\ Ancient Techniques}

In the study of wire in antiquity it is the examination of gold jewellery which is most productive of evidence as the gold, duc to its freedom from corrosion, preserves the marks made on the surface during manufacture, unless they have been crased by excessive wear. Hence for the demonstration pieces of wire made to illustrate this paper (Figures 5 and 6), 22 carat gold was used which was kindly provided by Johnson Matthey.

\section{Hammering}

The simplest and most basic method for the manufacture of wire is to hanmer an ingot out until a wire with a more or less round and even section is produced (Figure 5c). This process is not as casy as it sounds, and it generally gives rise to a wire with a facetted surface, such as was noted by Flinders Petrie (32). A hoard of Bronze Age metalwork discovered in Central Europe and published by Pič (33) graphically illustrates the process as it contained examples of one type of ornament at several stages of manufacture, from long thin ingot, to facetted rod of approximately square section, to a spiral of wire (Figure 7, Nos. 12, I1, 16 and 18). The characteristic features of hammered wire are:

(i) Variations in diameter along the length.

(ii) A facetted surface (i.c. a non-round crosssection), although this call be eliminated to some extent on soft metals, such as pure gold, by rolling between two flat pieces of hard wood. (iii) Longitudinal "creases" (caused by hammering but sometimes mistaken for striations caused by drawing). These in no way resemble drawing striations, and are usually only a few millimetres in length.

(iv) A solid cross-section.

It is possible that a swage-block may sometimes have been used as an aid in the production of wire by hammering, but no observer scerns to have reported any evidence to suggest that this was so and the origins of the swage-block itself are obscurc, though Manning has recently reported two examples from a Late Iron-Age find in Britain (34).

\section{Block-Twisting}

The second method of making a solid wire is best described as block-twisting. It seems to have been first recogmised and described by Maryon (35), although his brief description was ignored by later authors until it was described and illustrated by Higgins (36) in his discussion of the authenticity of some Greek goid wirc. Block-twisted wire is made by hammering out an ingot to give a rod of the required thickness for the wire, but of a square section. The square rod is then twisted as tightly as possible (to give a barley-sugar effect) and then rolled between two flat picces of hard wood. The result is a piece of wire whose characteristics are:

(i) A fairly even diameter along the length.

(ii) A more or less round cross-section with a solid interior.

(iii) A smooth surface.

(iv) Four independemt spiral grooves on the surface, corresponding to the centres of the original four faces of the square wire.

With very soft metals, such a pure gold, these grooves can be completely eliminated during the rolling process, but careful searching often reveals occasional traces on ancient wires made by this technique. Four stages in the making of gold wire by this method, from square section rod to twisted and rolled wire, are illustrated in Figures $5(a)$ to (d).

One very simple way of makiug the square-section rod, which is the first step in this method of making wire, is to beat out the ingot into a sheet and then cut a strip from the edge which has the same width as the thickness of the sheet. This method of making wire scems to be described in Exodus 39.3:

"The gold was beaten into thin plates, cut and twisted into braid to be worked by a seamster with the violct, purple and scarler yarn and fine linen." This translation is taken from The New English Bible, but the Authorised Version has:

"beat the gold into thin plates and cut into wires ...", the essential differences being the addition of the 


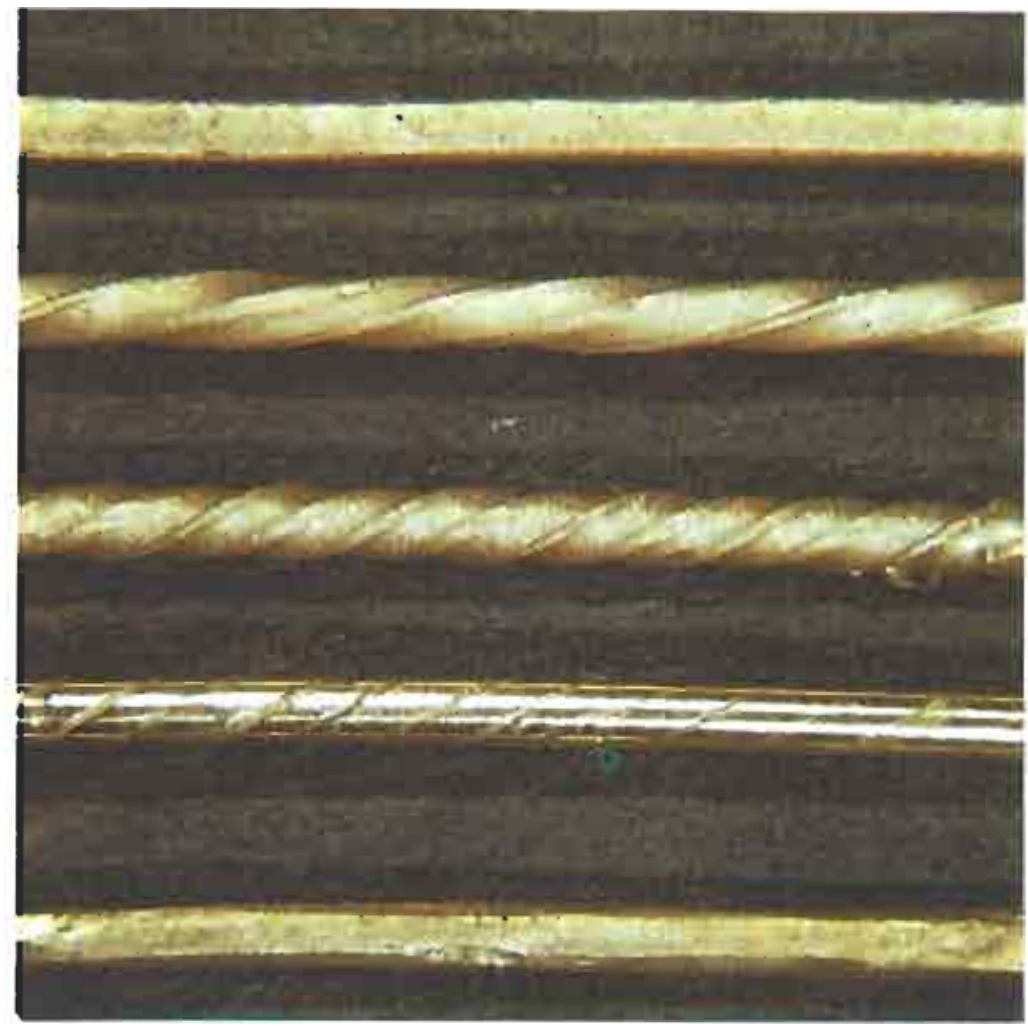

Fig. 5 Stages in the rcproduclion of the methods of lond-making gold wire in intiquity

(n) Square section rol for making into black-twinted wire

(b) The anme rod after loosely ivisling

(c) The rod twislet as lightly as pousible and now ready for rolling

(d) The finished hlock-lwisled wire showing four independent helical creatites

(e) Hanmered wire ghowing the inevitable faceting of the murface

"twisting" stage in the new translation but the replacement of the word "wires" by "braid". This creates a problem because the usual way of making gold thread for weaving into cloth was to twist strips of gold foil round a strand of silk in a helical fashion (4), and it is conceivable that this is the process being described here, though the manufacture of a straightforward solid wire seems more likely. Whatever the interpretation put on this passage, there is no doubt that block-twisting was known and used in the Bronze Age for making wire. Sometimes the final rolling stage was omitted, and the wire left with its "barlcysugar" shape to add to the decorative effect.

\section{Strip-Drawing}

The two remaining methods of making wire by hand both start with strips of metal foil and produce a wirc which is, in reality, a hollow tube. The first of these, strip-drawing, was recognised and described by Caroline Ransome Williams $(29$, p. 41) and involves taking a strip of metal foil and drawing it through a scries of holes of decreasing diameter so that the strip curls in upon itself to form a hollow tube, Figure 6 (a) to (c). Unlike normal wire drawing, the wirc is not significantly increased in length with each pull through the next smaller hole, and Williams has suggested that the "draw-plate" need not be made of metal, because of the relatively small strain put on it by the process, but could be made of hard wood or bone. It is also possible that holes of different diameters in precious stones could be used for this purpose, and these would be regarded as beads or amulets by a modern excavator, possibly cxplaining why no "draw-plates" have been recognised. Tho characteristic features of strip-drawn wire are:

(i) Very even diamerer along the length.

(ii) Round cross-section with a hollow interior.

Williams has suggested that it is, in fact, possiblc to continue drawing until the wirc has curled in upon itself complctely and eliminated the hollow interior. This can happen when very soft metal is uscd, but as the wire decreases in diameter the tendency to break during pulling increases, and it scems inore likely that most wires made by this process are hollow. Cutting, however, invariably presses the oppositc sides of the void together so that cut ends do appear solid.

(ii) A longitudinal seam which is gencrally more or less parallel with the long axis of the wire, but which may wander from side to side to some extent, or even form a holix, depending on variations in thickness and width of the original strip of foil used to make the wire.

(iv) A series of very fine parallel scratches on the surface resulting from the use of a metal dic for pulling. It is possible that this feature docs not appear on strip-drawn wirc pulled through holes in wood, bone or stone, depending on 


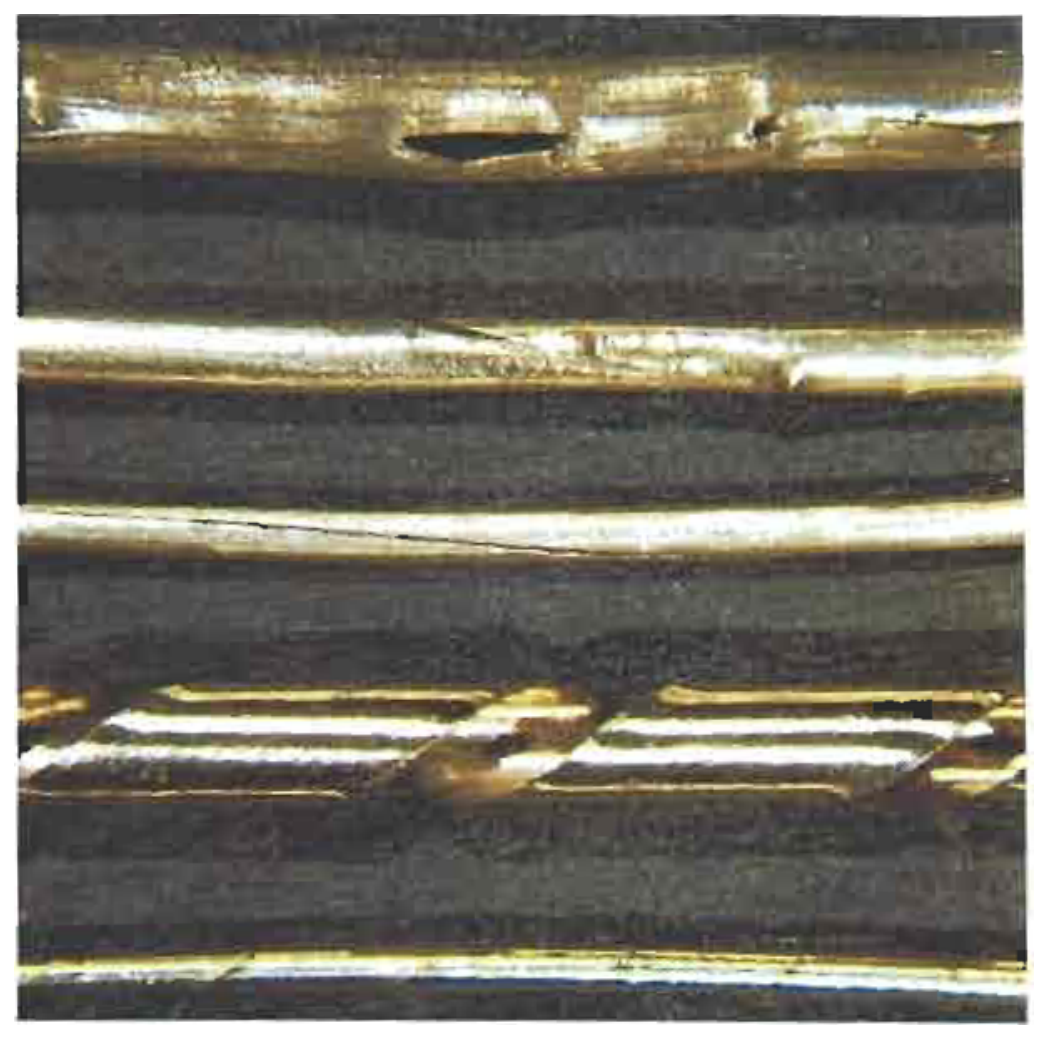

Fig. 6 Slages in the reproduction of atrip-drawn and atrip-lwisted gold wire

(a) A mirip of gold after drawing llorougl the first hole so lhal it is curled up to form a tube, A hole is visible in one place where the two edges lhis'c nol yet met

(b) The same apecimen after pulling ilyough furlher holes. The diam. eter has been reduced as the foil curls more lightly on itsedr

(s) The finihed example of stripdruw'n wire, The single longiludinal nenm is elearly visible

(d) A strip of gold loosely twisted into a hetix as the first ntage of making strip-twiated wire

(o) The finithed example of atrip. twisted wirc. The gingle helical seam is not very visible in the plotograph

how smooth the holes are, but a metal dic will always leave this characteristic pattern of fine lines, which can be seen only under a microscope.

\section{Strip-Twisting}

The final technique for making wire by hand is known as strip-twisting (or somerimes as strip-coil or soda-straw twist). It was also described by Caroline Ransome Williams, and in greater detail by Diane Lee Carroll (31) and Aine Thouvenin (37), The latter regarded it as the main technique for making wire in antiquity before true drawing of solid rod was invented, although she, like Carroll, postulated that after the strip had been twisted as tightly as possible it was improved and made more regular by pulling it through a series of dies, in a similar fashion to the making of strip-drawn wirc, although in this case the hollow tube is formed before passage through the dic.

The technique of strip-twisting involves cutting a strip of inetal foil and wrapping it round an existing wire which is then removed. This helix is then tightened and gently extended by hand. The best wires result when each turn of the helix slightly overlaps the edge of the previous one, but sometimes the turns separate and, as they are lightened by twisting the edges, meet again and push together with a resulting deformation of the wire which has been illustrated by Thouvenin. The stages illustrated here (Figure 6 (d) and (c)) show a loose spiral and a wire which was made with the successive turns overlapping slighrly. The characteristic features of strip-rwisted wire are:

(i) Fairly even diancter, though this may vary in a regular manner if the twisting is tighter at one end of the wire than the other.

(ii) Round cross-section with a hollow interior.

(iii) Single seam running in a helix round the wire.

(iv) If a series of dies have been used to smooth the wire it may show a surface pattern of very fine parallel scratches.

Diane Lec Carroll suggests that strip-twisted wire was always drawn through dies to finish it off and thinks that the technique is to be associated with the Grecks and Etruscans, while the strip-drawing technique was initiated by the Egyptians, and possibly their neighbours in the Near East. This is only a tentative conclusion and recent research on Cypriot jewellery has shown that in the Bronze Age gold wire was made by hammering and block-twisting and apparently not by strip-twisting (10) and it is clear that large numbers of new and objective examinations must be awaited before a complete picture of hand made gold wire in antiquity is available.

That large numbers of examinations of ancjent wire are needed in the light of these critcria is well illustrated by the recent papers of Thouvenin (37) and Kratz (38). The former assumed that before 


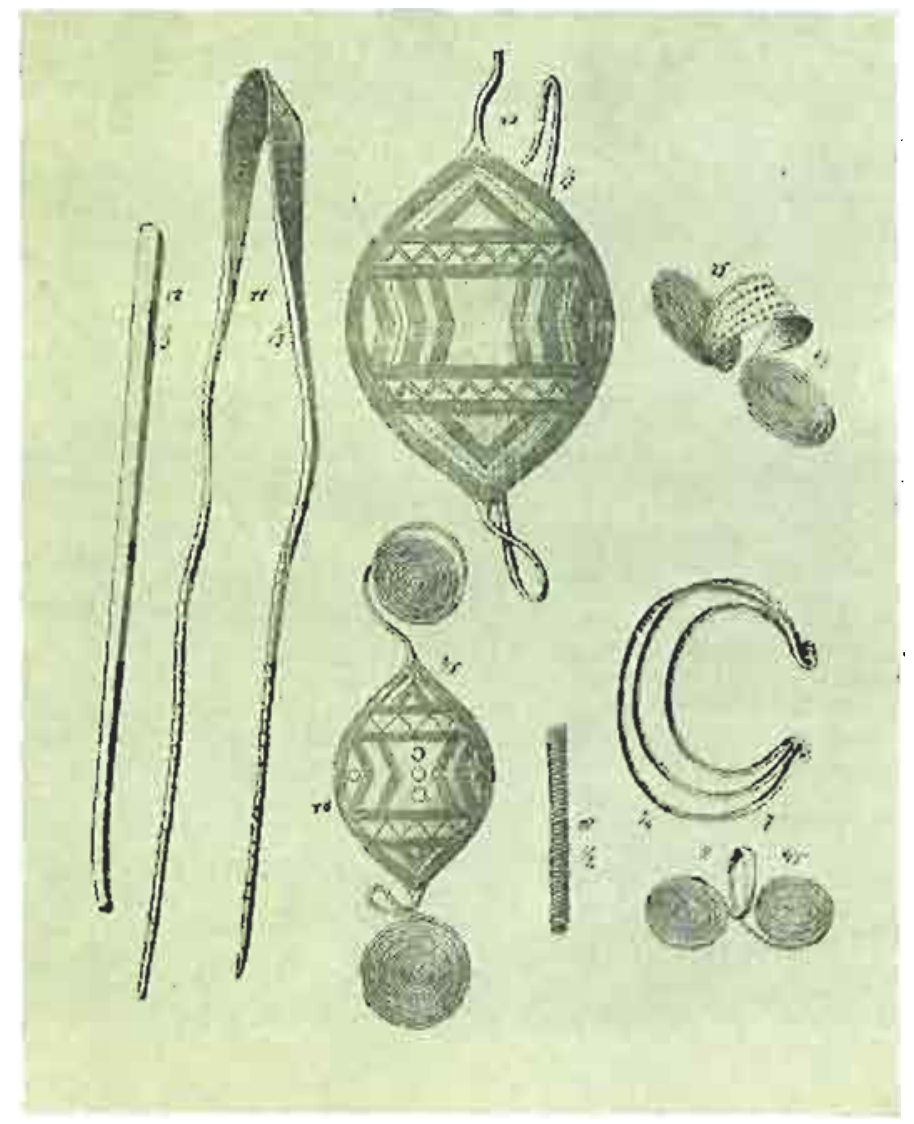

Fig. 7 Objects from a hoard from the mid-fint millenium B.C. found in Czechoulovakia in which hammered wire is ghown in various stages of nuanufacture. Block-t wisting is probably reprewented by No.9 (After J. L. Pí, Ref. 33)

Epprecht and Murz have published mctallurgical studies of five fragments of bronze and brass wire of Roman date and come to the conclusion that the wire was unmistakably drawn (40). Whether their metallurgical evidence would also fit wire made by hammering or block-twisting is impossible to say until examinations have been carricd out on modern brass and bronze wires made by all methods, but one of their fragments rctains traces on the surface of a series of fine parallel groves which secm to be unmistakably the result of drawing through a metal plate. In fact Ohllaver has published illustrations of three iron tools with a series of holes from Gallo-Roman excavations at Chatelet in the Champagne

the invention of the draw-plate all gold wires were made by strip-twisting followed by smoothing by pulling the wire through a narrow holc or holes, while the latter thought that thick wire was made by hammering while thin gold wire was made by blocktwisting. The paper by Kratz is well illustrated by photomicrographs of ancient jewellcry which he has examined, and in many cases the wires show the helical creases that are characteristic of block-twisting, but it is very surprising that Kratz has never recognised evidence for strip-drawing or strip-twisting among the many objects he has examined. It is of course possible that the different methods of handmaking wire had a geographical significance as Carroll has suggested (31), although her simple division between Egypt and Western Asia on the onc hand and the world of the Greeks on the other needs further proof, and it is also possible (though inhercntly unlikely) that different techniques werc employed according to the alloy which was to be used. Thus Kratz (38) is adamant, in the light of all his cxaminations, that drawing of gold wire was an invention of the tenth or eleventh century A.D., in spite of the various carlier wire-drawing plates which had already been published. Raub has recently carried out an examination of a gold necklace of Roman date (39) which is undoubtedly block-twisted, but
(27), but altbough he thought that at least two of them were for wire-drawing, the original objects are, apparently, lost.

This paper has attempted to bring together the historical and archacological evidence for the history of hand-made wire which has accumulated in recent years. As Hawthorne and Smith said in a footnote to the chapter on the draw-plate in their cdition of Theophilus:

"There is no satisfactory history of the origin and development of wire-drawing, despite its central importance among metal working processes",

and what this paper has tried to demonstrate is that such a "history" cannot yet be written until large numbers of ancient wires have been fully examined and correctly described.

\section{Ackuowledgenents}

The author is indebied to many friends and colleagues for useful and encouraging discussion and for access to the British Museum coltections of antique jewellery. Especial thanks are due to Miss Mavis Bimson for initially demonstrating block-twisting and strip-twisting, to Mr. Jack Ogden for placing his own knowledge of wire making in antiquity at my disposal, to Dr. B. Arrhenius of Stocktolm for supplying a photograph of the draw-plate from Birka, to Dr. R. Pleiner of Prague for drawing my attention to the article by $\mathrm{Pix}$, and to Mr. A. E. Whitaker for translating several refercnces from Gerinan. Not least I am grateful to Dr. Leshie Hunt whose gentle persuasion has brought the work to fruition. 
1 Friedrich Bock, "Deutsches Handwerk im Mitcelalter", Leipzig, 1935; W. Treue et al; "Das Hausbuch der Mendelschen Zwülfbröderstiftung zu Nürnberg", München, 1965; H. Ohlhaver, "Der Germanische Schmied und scin Werkzeug", Hamburger Schrifien zur Vorgeschichte und Germanischen Frahgeschichre, 1939, 2, 75-80

2 Theophilus, "De Diversis Artibus", Book IIl, Chapter VIII. For translations into English see C. R. Dodwell, "Theophilus: The Various Arts" ${ }^{\text {s }}$ London, 1961, p. 68. J. G. Hawthorne and C. S, Smith, "On Divers Arts: The Treatise of Theophilus", Chicago, 1963, pp. $87-89$

3 R. P. Hommel, "China at Work", New York, 1937 (reprinted M.1.T. Press, Cambridge, Massachusets, 1969), pp. 25-27

4 H. E. Wulff, "The Traditional Crafts of Persia", M.1.T, Press, Cambridge, Massachusetrs, 1966, pp. 42-46

$5 \mathrm{~J}$. Necdham, "Science and Civilisation in China: Vol. IV Physics and Physical Technology: Part Il, Mechanical Engineering", Cambridge, 1965, p. 59

6 L. Aitchison, "A History of Metals" (2 vols), London, 1960, D. 214

7 C. Singer et al, "A. History of Technology: Volume 1I, The Mediterranean Civilisations and the Middle Ages", Oxford, 1956, pp. 481-2

8 C. H, V. Sutherland, "Gold: Its Beauty, Power and Allure", London, 1959, p. 36

9 C. Frémont, Etudes Expérimentales de Technologie Industricle, No, 72: l'Essal de Traction des Metaux, Paris, 1927

10 W. A. Oddy, unpublished results

11 E. Anastasiadis, "Bronze Welding, Riveting and Wiremaking by the Ancient Grecks", Metal Progress, 1950, $58,322-324$

12 J. Beckmann, "A History of Inventions", London, $1846, \mathrm{pp} .414-424$

$13 \mathrm{~J}$. Petersen, Vikingetidens Redskaper, Oslo, 1951, pp. 99-101

$14 \mathrm{~B}$. Arrhenius, "Ett traddragningsinstrument fran Birka", Forvanmen, 1968, 63, 288-293

$15 \mathrm{H}$. Vierck knows of a late sixth century A.D, draw-plate personal communication

16 F. C. Thompson, "The Early History of Wire", The Wire Indusiry, 1935, 2, 159-162

17 K. B. Lewis, "Wire Beginnings", The Wire Industry, $1936,3,4-9$ and $49-57$

18 E. Boileau, "Reglements sur les Arts et Meriers de Paris Redeges au XIII Siecle", Paris, 1837, pp. 74-76

$19 \mathrm{P}$. Longmuir and J. Kenworthy, "Early Wirc-Drawing Practice", Engineering, 1913, Aprit 18, 540-543

20 The De La Pirotcchnia of Vannoccio Biringuccio was published in Venice in 1540. It is available in English tranglation: $C$. $S$. Smith and $M$. T. Gnudi, "The Pirotechnia of Vannoccio Biringuccio". New York, 1942

21 "Eigentliche Beschreibung aller Stände auf Erden... Durch den weitberumpten Hans Sachsen", (Woodcuts by Jost Amman), Frankfurt, 1568
22 C. Wcigel, "Abbildung der gemeinnïtzlichen Haupstände", Regenspurg, 1698

$23 \mathrm{H}$. W. Paar and D. G. Tucker, "The Technology of Wirc Making at Tintern, Gwent, 1566-e. 1880", f. Hist. Metallurgical Soc., 1977, 11, (1), 15-24

24 C. Singer et al, "A History of Technology: Volume II, The Mediterranesn Civilisations and the Middle Ages", Oxford, 1956, p. 75

$25 \mathrm{E} . \mathrm{G}$. Thomsen and H, H. Thomsen, "Early Wire Drawing Through Dies", 7 . of Engineering for Industry (Trans. Am. Soc, Mech. Engincers, Serics B), 1974, 96, (4), 1216-1221

26 A. Oldeberg, "Metalltecknik under Vikingtid och Medeltid", Stockholm, 1966, Figs 79 and 80

$27 \mathrm{H}$. Ohihaver, "D $\mathrm{Cr}$ Germanische Schmied und sein Werkzeug", Hamburger Schriftent zur Vorgeschichte mod Germanischen Frihgeschichte, 1939, 2, 75-80

28 E. G. Thomsen and H. H. Thomsen, "Drawing Solid Wires through Soft Dies in Antiquity", $f$, of Enginetring for Industry (Trans. Amt. Soc. Mech. Ergincers, Serjes B) $1976,98,(1), 201-205$

29 C. R. Williams, "Catalogue of Egyptian Antiquitics: Gold and Silver Jewelry and Related Objects", New York Historical Socicty, New York, 1924, pp. 39-44

30 D. L. Carroll, "Drawn Wire and the Identification of Forgeries in Ancient Jewelry", American $\mathcal{f}$. of Archacology, 1970, 74, 401

31 D. L. Carroll, "Wire Drawing in Antiquity", American 7. of Archaeology, 1972, 76, 321-323

32 W. M. Flinders Petrie, "Diospolis Parya: The Cemeteries of Abadiych and Hu", London, 1901, p. 25

$33 \mathrm{~J}$. L. Pic, "Hromadný nález bronzu u JenSovic", Pamatky Archacololigickd a Mistopismd, 1896-97, 17, 693-702, especially plate 82

34 W. H. Marning, "Blacksmiths' Tools from Walthan Abbey, Essex", in "Aspects of Early. Metallurgy" (ed. W. A, Oddy), Historical Metallurgy Socicty, 1977, 87-96

35 H. Maryon, "The Technical Methods of the Irish Smiths in the Bronze and Early Iron Ages" , Proc. Royal Irish Acadeny, 1938, 44 (Secion C, No. 7), 181-228, especially p. 186

$36 \mathrm{M}$. Binson, quoted by R, A. Higgins, "Four Greek Roscltes Again", British Museum Quarterly, 1968-69, 33, 110-113

37 A. Thouvenin, "La Fabrication des Fils et des Filigranes de Metaux Precieux chez les Anciens", Revic d'Histoir des Mines at de la Mésallurgie, 1971, 3, 89-108

38 A. Kratz, "Goldschmiedetechnische Untersuchung von Goldarbejten inx .... Statlichen Museen ... Berlin", Aachener Kunstbläter, 1972, 43, 156-189

39 C. J. Raub, "Technologische Untersuchung einer rómischen Goldkette aus Malen", Fundberiehte ans Bades-Wirnomberg, 1977

40 W. Eppreche and A. Mute, "Gezogener römischer Draht", Jahrbuch der Schweizcrischen Gesellschaft far Ur- and Truhgeschichte (Basel), 1974-75, 58, 157-161

$\mathbf{I}^{\mathrm{N}}$

$\mathrm{N}$ gold the following properties meet. It is yellow in colour; heavy up to a certain weight; malleable and ductile to a certain degree of extension; it is not volatile and loses none of its substance by the action of fire.

From the translation by

FRANCIS BACON

Rober Ellis and James Spedding,

Novum Organum

I.ondon, I857

London, 1620 